\title{
Los dos CUerpos Del ARTista. El CUERPo AMADO Y EL CUERPO POLÍTICO.
}

\author{
The Two Bodies of the Artist. The Loved \\ Body ANd THe Political Body
}

ESTHer GonzÁlez GeA

Universitat de València

Recibido: 31/03/2017 Evaluado: 19/04/2017 Aprobado: 16/01/2018

RESUMEN: El presente trabajo analiza las imágenes generadas en torno a los artistas una vez fallecidos. Pues como cualquier individuo, su cuerpo efímero acaba en la putrefacción, mientras que su condición de personaje público lo distancia del resto proporcionándole otras existencia para ser honrado. De esta forma, su memoria pervive. En primer lugar, se recorrerán los precedentes de la imagen fotográfica post mortem para posteriormente explorar algunas imágenes fotográficas de artistas muertos durante los siglos XIX y xx, haciendo especial hincapié en las dudas que suscita el ámbito nacional y en la doble función de estos artefactos: como objeto de recuerdo y como signo de propaganda, ya que ambas ideas conviven en este tipo de documento. Finalmente, el artículo se centra en el entierro de Vicente Blasco Ibáñez, sus fotografías post mortem y los problemas que las rodean.

Palabras clave: fotografía post mortem, tradición, recuerdo, poder, Vicente Blasco Ibáñez.

ABSTRACT: The present text analyses a number of images of artists created after their deaths. Like any other individual, their ephemeral bodies are destined to rot, while their public figures provide another body to be honored, setting them apart from others. In this way, their memories are kept alive. Firstly, the paper reviews the precedents of post-mortem im- 
agery, and it then explores some photographs of deceased artists from the 19th and 20th centuries, with a focus on issues emerging from the national context of each and from and the double-layered meaning of these artefacts, which serve both as memorial objects and as signs of propaganda, the two dimensions coexisting in this type of document. Finally, the paper examines the burial of Vicente Blasco Ibáñez, his postmortem images and the issues they raise.

Keywords: Post mortem photography, tradition, memory, authority, Vicente Blasco Ibáñez.

\begin{abstract}
A veces la historia es injusta y no importa para qué siguen creciendo los árboles. Ni está bien ni está mal. Las cosas son así. Es posible que la culpa la tengan los hombres, pero nadie les va a pedir cuentas. No me llevo ninguna piedra, ninguna piedra pequeña del cementerio civil de Valencia. Tengo de otros. De aquí no las necesito. Max Aub, La gallina ciega. Diario español, 1971
\end{abstract}

\title{
BREVE HISTORIA DE LA MUERTE Y EL RECUERDO
}

T a aparición de la fotografía sirvió para cubrir las ausencias de la memoLria de un público mayoritario, pero como era lógico, también se usó para inmortalizar a los artistas y hombres ilustres, al margen de su legado. Este medio se presentaba como una vía para captar un fragmento de la realidad y, al mismo tiempo, como una suerte de arma que engaña. La ausencia real y la ficción -la representación- caminaron unidas desde el principio. Consciente de ello, ya en 1840, Hippolyte Bayard se autorretrata como hombre ahogado y Henry Peach Robinson compondrá en 1858 Fading Away. En ambas imágenes aparece la falsa muerte como un evento espectacularizado.

Más allá del retrato fotográfico, y al mismo tiempo que este, nació la fotografía post mortem. La muerte se había filtrado fuerte en el imaginario colectivo gracias a los pasos previos de los románticos y los artistas finiseculares. Así, el retrato fotográfico post mortem, venía a cumplir distintas funciones: por un lado, servía para unir lazos de parentesco, dar testimonio de una defunción y, sobre todo, para recordar al ser ausente; y por otro, atestiguaba la muerte del hombre y el cuerpo sin vida quedaba expuesto como representación. Debemos, además, recordar que la misma palabra retrato, del latín retractus, significa volver a traer. De este modo, tanto la naturaleza del soporte fotográfico como el género específico recogen la idea común de recuerdo, lo que refuerza todavía más la existencia del retrato fotográfico post mortem como lugar de la memoria.

El tratar de conservar la huella del desaparecido en una imagen que a la vez sirviera de objeto de devoción y exhibición nace muchísimo antes que la foto- 
grafía. Algunos autores señalan sus orígenes ya en el Neolítico con los cráneos de Jericó. ${ }^{1}$ Pero la necesidad de una imagen sustitutiva del cuerpo efímero y los ritos en torno al enterramiento se instituyeron en las denominadas culturas clásicas. Las honras fúnebres en honor a los grandes hombres surgieron y se desarrollaron en la Grecia clásica y la República romana, estableciendo referentes que fueron recuperados durante el Renacimiento. Estas ceremonias sobrevienen en el espectáculo de la representación del poder. ${ }^{2}$ Para ello, las imágenes desempeñan un papel fundamental que podemos rastrear desde la antigua Roma: para poder ejercer en la comunidad, los difuntos necesitaban cuerpos. La intención primordial de esta tradición era mantener o restablecer la presencia del difunto en la vida pública, de hecho, tales eran las influencias de algunos antepasados en el Estado que finalmente las ceremonias fueron suspendidas por cuestiones políticas. Las representaciones públicas idealizaban la muerte transformando al difunto como resume Belting en «un modelo a seguir que se mantiene con vida en la memoria social». ${ }^{3}$

Llegada la Edad Media, el culto a los personajes célebres contó con toda una panoplia que muchas veces rozaba lo teatral. Se tenía que demostrar que los altos mandatarios y personalidades ilustres eran dignos de proseguir con la estirpe y ostentar los privilegios que su antecesor poseía, nada mejor que imponer la supervivencia del poderoso a través, de nuevo, de la imagen-huella. Así, idearon la efigie real. En Inglaterra, la exhibición de efigies en los funerales data de 1327, las cuestiones pueden ser prácticas -en muchas ocasiones tardaban meses en enterrar a los cuerpos-, pero no son las únicas. ${ }^{4}$ Debajo de la imagen real hallamos el cuerpo efímero. Kantorowicz no duda en afirmar que «la efigie del rey en los ritos funerarios del siglo Xvi pronto se equiparó, o incluso eclipsó, a la del propio cuerpo difunto». Por supuesto la presencia de la efigie estaba asociada a las ideas políticas de la época, indicando que:

[...] la real Dignidad nunca moría y que en la imagen continuaba presente la jurisdicción del rey muerto hasta el día de su entierro. Bajo el impacto de aquellas ideas [...] el ceremonial relacionado con la efigie comenzó a llenarse de nuevos elementos y a afectar profundamente al propio clima funerario: un nuevo elemento triunfal, ausente en la época anterior, se introdujo en la ceremonia. ${ }^{5}$

1. Hans Belting precisa que «las primeras imágenes del culto a los muertos más antiguas que se conservan se han encontrado a partir de la Fase B precerámica del neolítico, y están fechadas alrededor de siete mil años antes de nuestra era [...] durante la cual surgió la primera sociedad sedentaria». HANS BELTING: Antropología de la imagen, Katz, Madrid, 2007, p. 186.

2. Víctor Mínguez: «Tumbas vacías y cadáveres pintados, el cuerpo muerto del rey en los jeroglíficos novohispanos, siglos XVII y XVIII», en e-Spania, 17, 2014, p. 2.

3. Belting: Antropología, pp. 206-207.

4. En el entierro de Eduardo II de Inglaterra se introdujo por primera vez sobre el féretro real la «representación» ad similitudinem regis, con el rostro, al parecer, extraído de una máscara mortuoria. ERNST H. KANTOROWiCZ: Los dos cuerpos del rey: un estudio de teología politica medieval, Alianza Editorial, Madrid, 1985, pp. 392-393.

5. Ibid., pp. 395-396. 
El cuerpo se vio desprovisto de señas de identidad mientras que el doble era coronado con los atributos propios a su cargo. Con estas ceremonias se ponía de relieve la idea de que tenens dignitatem est corruptibilis, tamen semper est, non moritur «el poseedor de una dignidad es corruptible, pero la dignidad es para siempre, nunca muere». Por fin, los juristas descubrieron como hacer inmortal la naturaleza efímera, algo que en el Renacimiento se intensificó. ${ }^{6}$

En la Edad Moderna la individualidad extendió el deseo de inmortalidad sobrepasando la monarquía. Ya en el siglo XVI, los nobles y adinerados gustaban de retratar a sus seres queridos desaparecidos. Y como era normal, en una época en la que el hombre pasó a ser el foco de atención, los artistas cobraron no solo prestigio en la sociedad sino que en algunos casos se convirtieron en auténticos protagonistas. Sabemos de la existencia de la huella física, las máscaras mortuorias, desde el siglo Xv. ${ }^{7}$ Sin embargo, el verdadero boom de estos artefactos miméticos del rostro humano asociado a los artistas lo podemos situar y cuantificar en el siglo XIX. ${ }^{8}$

También del siglo xix data la moda de los retratos en miniatura, que se ha asociado a la tradición del libro miniado y evolucionó a raíz de ciertas motivaciones como enviar retratos a las familias lejanas dando testimonio de los acontecimientos en la comunidad: nacimientos, matrimonios, viajes y, por supuesto, defunciones. ${ }^{9}$ Este género pictórico, ligado irremediablemente al ambiente aristocrático y burgués, fue desplazado hasta desaparecer con la llegada de los primeros daguerrotipos. ${ }^{10}$

6. KANTOROwicz: Los dos cuerpos del rey, pp. 407-408.

7. Existen extensos estudios sobre las efigies reales, como el ya citado de Kantorowickz, Los dos cuerpos del rey: un estudio de teología política medieval. En el caso del tema de las máscaras mortuorias, podemos recurrir al libro de ERNST BENKARD: Rostros inmortales. Una colección de máscaras mortuorias, Sans Soleil, Barcelona, 2013; y al clásico de Maurice Bessy: Mort où est ton visage?, Editions du Rocher, Mónaco, 1981. Para complementar estas ideas, se recomienda la consulta del artículo de GORKA LÓPEZ DE MunAIN: «Las imágenes postmortem del poder: el lecho fúnebre como escenario político» en http://cort. as/-C2S8 (Fecha de consulta: 25/2/2016) o la tesis doctoral del mismo autor, GorKA LÓPEZ DE MUNAIN: Una genealogía de la máscara mortuoria. Tiempo, imagen y presencia, Tesis doctoral, Universitat de Barcelona, Barcelona, 2017.

8. BenKard, Rostros inmortales, p. 34.

9. El retrato en miniatura no nació en el Renacimiento sino que sus orígenes iconográficos los podemos rastrear desde la Antigüedad en monedas, anillos, sellos o espejos. Este modelo pasaría después a los códices miniados, pero fue a partir de finales del siglo xv cuando por primera vez se consiguió el carácter portátil y se realizaron los primeros retratos en miniatura independientes del códice. Estas primeras miniaturas, ejecutadas al temple sobre pergamino, dieron paso con el tiempo y una vez popularizada la técnica al óleo, a los retratos en miniatura. En el ámbito de la historia del arte se entiende por miniatura un retrato pequeño, transportable, de carácter íntimo hecho en distintos materiales con una ejecución detallista. En la mayoría de los casos estos retratos tenían una función esencialmente privada como memento de una persona querida que reflejaban vínculos de afecto con personas ausentes o muertas, cumpliendo una función similar a la fotografía. Dado su tamaño se podían transportar con facilidad y estrechaban lazos de parentesco. JULIA DE LA TORRE FAzIO: El retrato en miniatura español bajo los reinados de Felipe II y Felipe III, Tesis doctoral, Universidad de Málaga, Málaga, 2009, pp. 59-60.

10. Tanto Gisèle Freund en Gisèle Freund: La fotografía como documento social, Gustavo Gili Barcelona, 2011 como Walter Benjamin en alguno de sus artículos más famosos recogidos en WALTER BENJAMIN: Sobre la fotografía, Pre-Textos, Valencia, 2013 -entre otros- han comentado la vida relativamente efímera de la miniatura del siglo XIX. 
Con la llegada de la Edad Contemporánea, sencillamente las imágenes se pusieron a disposición de las tecnologías, como explica Debray, «las culturas de la mirada, a su vez, no son independientes de las revoluciones técnicas que vienen a modificar en cada época el formato, los materiales, la cantidad de imágenes de que una sociedad se debe hacer cargo». ${ }^{11}$

\section{De la hUElla SÓlida A la hUElla ÓPtica. LA Fotografía COMO LUGAR DE LA MEMORIA}

Desde la presentación de la fotografía a la sociedad en 1839 asistimos al inicio de los denominados medios de comunicación de masas. Con estos, el auténtico cambio en relación al recuerdo no se encuentra únicamente en la aniquilación del culto a la imagen, sino en el poder de exposición de la misma de forma masiva. Como bien expuso Walter Benjamin:

[...] el valor de exhibición empieza a hacer retroceder el valor de culto. Pero este no cede sin resistencia. Ocupa una última trinchera, que es el rostro humano. En modo alguno es casual que en los albores de la fotografía el retrato ocupe un puesto central. El valor cultual de la imagen tiene su último refugio en el culto al recuerdo de los seres queridos, lejanos o desaparecidos. ${ }^{12}$

El retrato fotográfico post mortem, se introduce en los ambientes privados, sin embargo, se conforma e institucionaliza en el ámbito oficial, ofreciendo la oportunidad de mostrar a los personajes célebres al gran público. Los medios de comunicación son los encargados de difundir estas imágenes en forma de portadas de periódicos y publicaciones varias. Aunque estas imágenes, más allá de su función mediática, representan a los individuos, es decir, hacen presente lo ausente; no se trata simplemente de evocar sino de reemplazar, «como si la imagen estuviera ahí para cubrir una carencia, aliviar una pena». ${ }^{13} \mathrm{La}$ diferencia esencial es que esa ausencia, ese vacío, cuando se trata de un artista o personaje famoso, no afecta solo a un pequeño reducto familiar, sino que afecta a más estratos de la población, dejamos de hablar del último/único retrato para devenir en el Último retrato. La memoria del espectáculo circula a una velocidad feroz desde los inicios de los medios.

Además, el componente de realidad, que en fotografía no es tanto su capacidad mimética sino su naturaleza de huella, reafirma al nuevo medio. ${ }^{14} \mathrm{La}$ supuesta objetividad de la fotografía trae consigo esa gran potencia de credi-

11. Regis Debray: Vida y muerte de la imagen: Historia de la mirada en Occidente, Paidós, Barcelona, 1994, pp. 38-39.

12. Benjamin: Sobre la fotografía, p. 106.

13. DeBray: Vida y muerte, p. 34.

14. Philippe Dubois: El acto fotográfico. De la Representación a la Recepción, Paidós, Barcelona, 1986, p. 31. 
bilidad que nunca consiguió la pintura como apuntó Bazin, ${ }^{15}$ ni siquiera las efigies reales o las máscaras mortuorias con el componente de huella tan evidente podían llegar a mostrar el simulacro en todo su esplendor. Por ende, la fotografía se muestra como el soporte idóneo para congelar la figura del artista y además hacer partícipe al público de la responsabilidad de su pervivencia.

A pesar de lo expuesto, toda imagen es un artificio, un producto construido y, como tal, la fotografía post mortem cabalgaría en esa línea divisoria tan difusa de la imagen reliquia y la imagen de poder, entendiendo que «el poder, para ser efectivo, debía inspirar afecto, y por ello en ocasiones debía descender al nivel de lo familiar». ${ }^{16}$ Nada más cercano que enfrentar al espectador a lo cotidiano, lo (re)conocido: el fin de la vida. Mostrar los cuerpos de los artistas en su última representación los volvía más mundanos para el gran público, fomentando empatía en un pueblo que necesita reafirmar sus valores y perpetuar sus orígenes. Todo ello contribuía, en suma, a la creación de la denominada memoria colectiva, la memoria social.

Lo curioso de la fotografía post mortem es que a pesar de su práctica habitual durante finales del siglo xix y gran parte de $\mathrm{xx}$-llegando hasta el actual siglo XXI-, ha sido un objeto silenciado y obsceno. Tenemos constancia de la existencia de un gran corpus de imágenes de artistas muertos en el mundo occidental dentro del periodo citado, si bien su visibilidad, conservación y estudio han correspondido al interés mostrado por las distintas instituciones o particulares de su lugar de origen. La mayoría de los lectores conocerá la fotografía de Victor Hugo muerto bajo el sello inconfundible de Nadar; en cambio, muchas son las cuestiones que la investigación debe resolver acerca de las imágenes póstumas de Antonio Machado o Joaquín Sorolla en su lecho de muerte, entre muchos otros.

\section{Retrato Fotográfico POST MORTEM DE ARTISTAS. El CUERPo AMADO Y EL CUERPO POLÍTICO}

La fotografía, como matriz de reproductibilidad técnica, cambió de forma radical la manera de multiplicar la memoria. No obstante, a pesar de la euforia inicial de poder duplicar la imagen, ésta proviene de un único negativo, de un «único cuerpo mortal». ${ }^{17}$ Así pues, si la fotografía transformó la muerte en un hecho más igualitario, «permitiendo que el arte ritual del retrato de difuntos adoptase nuevas formas de representación popular», ${ }^{18}$ también sirvió de

15. ANDrÉ BAZIN: «Ontología de la imagen fotográfica», en ¿Qué es el cine?, Rialp, Madrid, 2000, p. 28.

16. Philippe Ariès y Georges Duby: Historia de la vida privada. La Revolución francesa y el asentamiento de la sociedad burguesa, Taurus, Madrid, 1991, p. 31.

17. Belting, Antropología, 2007 p. 229.

18. EMili Luis LARA López: «La representación social de la muerte a través de la fotografía (Murcia y Jaén, 1870-1902): una historia de la imagen burguesa», en Revista de dialectología y tradiciones populares, 60, 2005, p. 138. 
último refugio del ser desaparecido y de consuelo para los dolientes, además, según las circunstancias, funcionaba de plataforma de ostentación.

Podemos afirmar, analizando el corpus de imágenes post mortem tanto fotográficas como pictóricas, que la representación de los cuerpos sin vida se construía siguiendo unos códigos narrativos visuales formados por estereotipos sociales mezclados con influencias artísticas anteriores, seguramente fruto de una interiorización de los modelos más que como simple emulación. Los códigos del retrato fotográfico post mortem desde el principio están sujetos a convencionalismos que se adscriben a modelos sencillos, en los que lo fundamental era que el cadáver apareciese sereno, como dormido, preferiblemente en su lecho íntimo, poniendo de relieve la buena muerte tan propia de los grandes hombres. ${ }^{19}$ Tampoco podemos eludir que las clases altas de la sociedad fueron las impulsoras de estos ritos a nivel mediático, las primeras que utilizaron el nuevo medio para inmortalizarse buscando la gloria eterna. En definitiva, recordemos que este tipo de imágenes -como la gran mayoríacontienen dos fines muy definidos: recordar y exponer la memoria del difunto.

Un simple acercamiento a estas representaciones fotográficas de personajes públicos en distintos lugares y momentos nos sitúa ante claves para comprender su doble función, y sobre todo, su fin primordial: el registro de un acontecimiento histórico. ${ }^{20}$ Como nombrábamos anteriormente, en muchos casos la utilidad de estos retratos de artistas fallecidos no está documentada, su destino es confuso; no obstante, sabemos de su existencia. En otros, en cambio, son imágenes sumamente conocidas, musealizadas y difundidas -quizá no tanto en la actualidad, pero de forma masiva en el momento de su creación-. Con todo, las figuras representadas son artistas con más o menos fama, pero reconocidos por su fortuna crítica en su época. En muchos casos, además, las instantáneas son tomadas por profesionales de prestigio como el retrato post mortem de Marcel Proust realizado por Man Ray, el de Jean Cocteau por parte de su colaborador y amigo personal Raymond Voinquel, o las famosas imágenes de Gustave Doré, Eugène Carriére, Marceline Desbordes Valmore, o la ya citada de Victor Hugo, todas provenientes de la mano del fotógrafo de

19. Para desarrollar más el tema de la importancia de la buena muerte asociada a los personajes ilustres remitirse Philippe Ariès: El hombre ante la muerte, Taurus, Madrid, 1983. Al respecto de las tipologías de los retratos mortuorios, hay autores que han mantenido la existencia de tres tipos de retratos que han evolucionado sujetos a los cambios en las mentalidades. Virginia de la Cruz siguiendo los estudios americanos sobre el tema distingue tres tipos: as alive, as asleep y as dead. Para ampliar, acudir a Virginia De LA CRUz: El retrato y la muerte. La tradición de la fotografía post mortem en España, Temporae, Madrid, 2013; o a la fuente de la que se nutre esta, Jay Ruby: Secure the Shadow. Death and Photography in America, MIT Press, Cambridge, 1995. Este último un estudio imprescindible sobre la fotografía post mortem americana.

20. Como formula Andrea Cuarteolo: «En el caso de los personajes públicos [...] era muy difícil que la fotografía post mortem fuera la única imagen que los retratara. Lo más frecuente era que contaran no con una sino con varias fotos tomadas en vida. En estos casos, además, la iniciativa del retrato raramente provenía de la familia. [...] ésta surgía, la mayoría de las veces, de los propios fotógrafos y hacia fines del siglo Xix fueron los mismos medios gráficos quienes comenzaron a encargarlas». ANDREA CUARTEOLO: «La muerte ilustre. Fotografía mortuoria de personajes públicos en el Río de la Plata», en Imagen de la muerte, Universidad Nacional Mayor de San Marcos, Lima, 2007, pp. 85-86. 
los individuos, Nadar. Pero, ¿qué sucede con otras fotografías post mortem de artistas como la de Mariano Fortuny y Marsal, Edvard Munch, Gustave Eiffel o Pío Baroja entre muchas otras? Las preguntas son inevitables: quién las tomó, quién las encargó, quiénes eran sus destinatarios.

Para ilustrar esta paradoja y tratar de verter luz sobre todo lo expuesto con anterioridad recurriremos a dos ejemplos concreto: por una parte, el sepelio y los retratos post mortem realizados a Victor Hugo o a Auguste Rodin por diferentes artistas y los medios donde se difundieron; por otra, en un apartado más extenso, las vicisitudes de la llegada de los restos de Vicente Blasco Ibáñez a Valencia, su ciudad natal, y las consabidas imágenes post mortem.

Víctor Hugo murió en 1885 en París (fig. 1). Desde un principio se entendió la relevancia de dicha defunción, y así lo demuestra el mecanismo que se orquestó alrededor del cuerpo nada más fenecer. Las necesidades de la prensa se antepusieron a cualquier duelo familiar, el cuerpo fue conservado inyectándole cloruro de zinc, e inmediatamente fueron convocados alrededor de este unos doce artistas entre pintores, ilustradores, escultores y fotógrafos de renombre que desplegaron sus virtudes en torno al personaje. La máscara mortuoria la elaboró el escultor francés Jules Dalou, de la cual se editaron posteriormente cartas postales impresas que se vendían con facilidad. El encargado de fotografiar al gran hombre fue Nadar, que previamente al disparo realizó un croquis de la posición que debía adoptar el cuerpo para medir minuciosamente la luz, redujo el escenario al mínimo dejando las sábanas blancas de la cama y colocando un telón negro detrás para recortar la silueta. ${ }^{21}$ La imagen fue celebrada

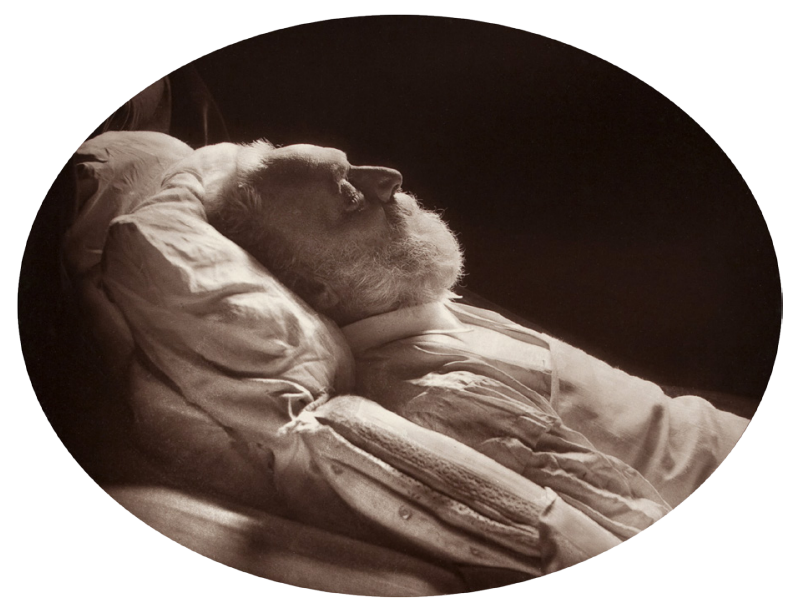

Fig. 1. Nadar, Victor Hugo sur son lit de mort, 1885, Musée d'Orsay, París

21. Para ampliar la información de cómo trabajaba Nadar el retrato fotográfico post mortem y, además, conocer a través de él algunas características del género acudir a: José FERNANDO VÁzQUEz CASILLAS: «La fotografía como documento sociocultural a finales del siglo xix: Nadar y el retrato post mortem», en Revista de Dialectología y tradiciones populares, 2, 2014, vol. LXIX, pp. 467-486. 
y acabó convirtiéndose en la portada de L'Illustration como sucedió unos años antes con la imagen de Gambetta realizada por Carjat - matizar que la imagen fue transformada en dibujo antes de publicarse, pues se consideró que el rostro estaba demasiado estropeado- y como sucederá posteriormente con la de Rodin en 1917.

La muerte de Rodin, a pesar de suceder en plena guerra, no impidió que la prensa se hiciera eco rápidamente. Diez fotógrafos fueron convocados para retratar el cuerpo sin vida del escultor. Compusieron la escena para que el conjunto recordase a las imágenes de santos o a las efigies medievales. Esto se aprecia sobre todo en el tratamiento del cuerpo, que fue vestido con una especie de hábito de monje, la idea general era que pareciera mort en odeur de sainteté (fig. 2). La sensación final que se perseguía era más emular una escultura que dotarlo de vida. El hecho de morir en el corazón de la guerra a una edad avanzada, plantea la cuestión de retratarlo más como genio que como héroe. Según el corpus de obras que manejaron los autores del catálogo del Musée d'Orsay, Le Dernier Portrait, la producción de este tipo de fotografías se redujo a partir de 1910, de ahí que surja la inevitable pregunta: ¿quizás la guerra desplazó el interés por el individuo hacia un interés por la colectividad?22 Puede ser que fuera así, aunque personalmente no creemos que se deba a una única razón, es más, una continúa búsqueda sobre la actividad fotográfica post mortem de ámbito público en diferentes regiones del planeta confirma la supervivencia del género, por tanto, la reducción no finaliza con escisión.

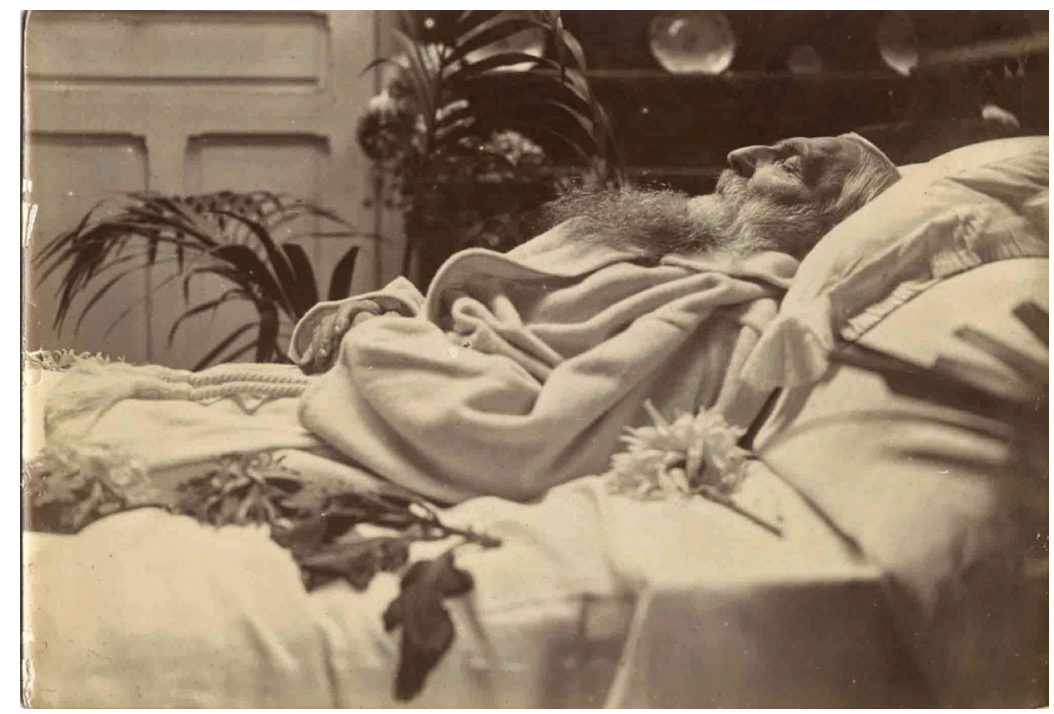

Fig. 2. J. Clair-Guyot, Rodin sur son lit de mort, 1917, Colección particular, París

22. Emmanuelle Héran et al.: La Dernier Portrait. Musée d'Orsay, 5 de mars-26 mai 2002, pp. 54-59. 


\section{Un PERIPLO EN IMÁGENES. LA MUERTE de ViCENTE BlasCo IbÁÑEZ}

Mientras que los casos sucintamente analizados sobre los retratos post mortem de algunos de los artistas citados y toda la ceremonia en torno al deceso del personaje célebre antes y después se encuentra suficientemente estudiado desde su lugar de origen, el caso de Vicente Blasco Ibáñez en España, su muerte en Francia y su posterior traslado a su ciudad natal, permanecen en penumbra. Para arrojar algo de luz a las numerosas incógnitas que surgen en torno a estas imágenes en principio tan inocentes, nos hemos acercado tanto a las fotografías post mortem del escritor tomadas en Fontana Rosa como a las instantáneas capturadas a lo largo de todo su traslado a territorio nacional, aunque tampoco hemos descuidado algunos de los monumentos proyectados alrededor de su memoria.

Vicente Blasco Ibáñez falleció en su villa de Menton (Francia) un 28 de enero de 1928, pero habría que esperar cinco años para que sus restos fueran trasladados a su ciudad natal como deseaba -el escritor dejó constancia en su testamento que sus restos solo entrarían en su patria bajo un gobierno republicano-. Con la II República instaurada en la ciudad de Valencia llegó el cuerpo del escritor a bordo del Jaume I. Para recibirle se organizó un multitudinario acto presidido por una comitiva oficial que partió de Menton, llegó al puerto de Valencia y acompañó sus restos mortales hacia La Lonja donde se dispondría la capilla ardiente, para finalmente trasladarlo al cementerio pasando por su primera residencia, algún lugar emblemático y, por supuesto, la sede del periódico El Pueblo. ${ }^{23}$

¡Cuanta emoción en los corazones, dolor en las almas, gestos de amargura en los rostros y ansiedad incontenible en todos los pechos! Ansiedad, sí; deseo infinito de hacerse pronto cargo de las cenizas del genial escritor valenciano para guárdalas cariñosamente en el regazo de la patria chica, y rendirles el tributo merecido: cariño, respeto, admiración. ${ }^{24}$

Con estas palabras describió Horacio G. de la Rosa la llegada de los restos del escritor a Valencia; sin embargo, años después, Max Aub en su libro La gallina ciega cuenta la impresión que recibió a su paso por Valencia del lugar donde descansaba Blasco Ibáñez:

Aquí, en el cementerio civil en un nicho con el alto relieve de mármol tallado muy modern style se lee Vicente Blasco Ibáñez y sus fechas (creo). Nada más. Bastante abandonado. Pequeña. Un nicho. Nada [...] Lo que importa, lo que me

23. Información extraída de: VICENTE MuÑoz Puelles: Informe sobre los restos de Vicente Blasco Ibáñez, Consell Valencià de Cultura, 31 de marzo de 2005; del archivo digital de la Diputación de Valencia y de la Biblioteca Virtual Miguel Cervantes.

24. Testigo directo del traslado del cuerpo de Vicente Blasco Ibáñez. Arte y Libertad, año Ix, 51, 29 de octubre de 2008, Valencia, p. 7. 
impresiona, es esa triste placa de mármol, más o menos solitaria de Blasco, ahí en el cementerio civil, escondida. [...] Lo triste es esto: esta placa de mármol de un estilo pasado de moda, abandonada, cerca del suelo, con los restos de medio siglo de su ciudad. ${ }^{25}$

En 1933, el Ayuntamiento de Valencia realizó un concurso para la construcción del mausoleo que albergaría sus restos y honraría su figura en el cementerio oficial de la ciudad. Finalmente se seleccionó la obra de Javier Goerlich Lleó (1884-1974), entonces arquitecto mayor de Valencia, que se inspiró en el panteón de Napoleón (figs. 3 y 4). De aquel proyecto nos quedan los planos y

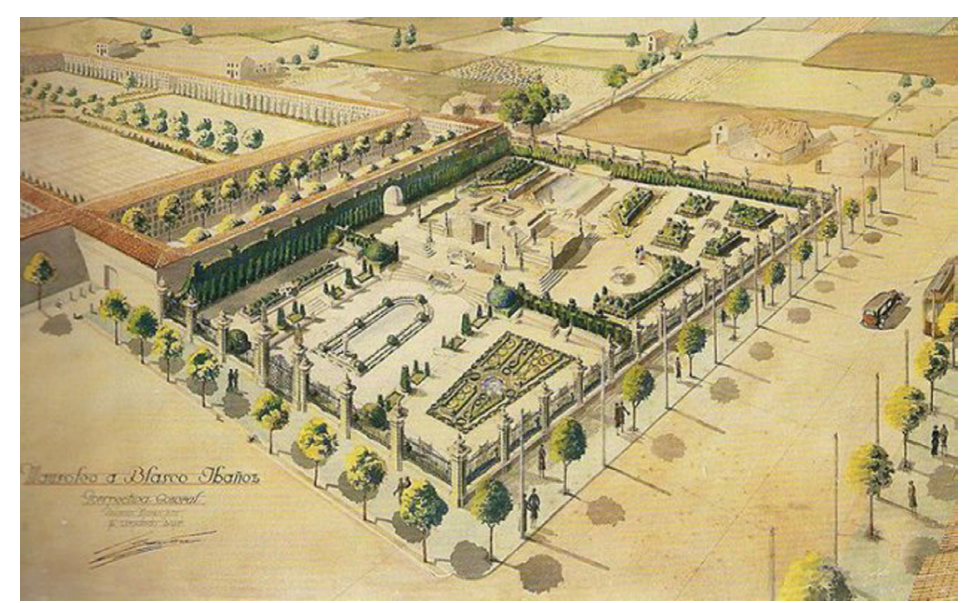

Fig. 3. Dibujos de la apariencia del Mausoleo, ca. 1933, Fundación Goerlich

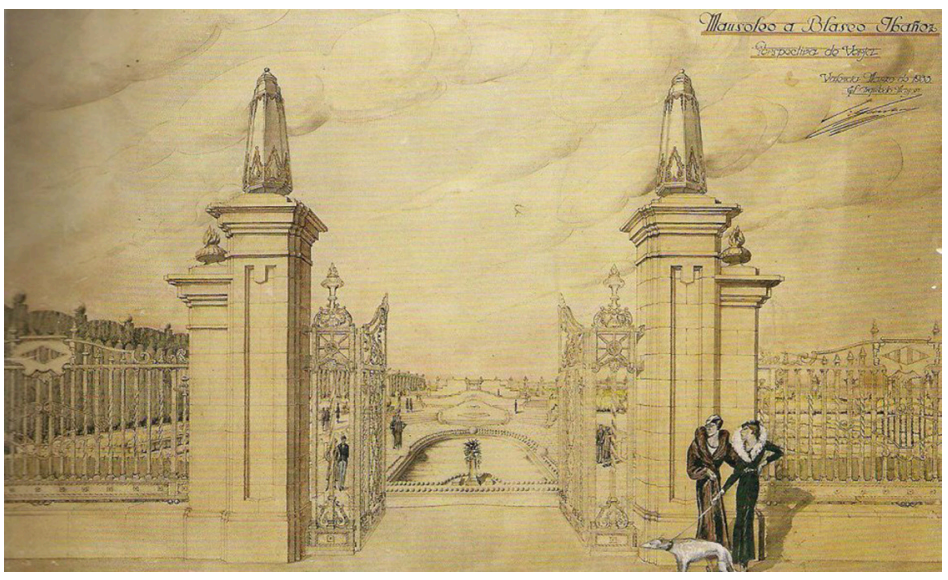

Fig. 4. Dibujos de la apariencia del Mausoleo, ca. 1933, Fundación Goerlich

25. Max Aub: La gallina ciega. Diario español, Alba, Barcelona, 1995, pp. 156-157. 
testimonios de quienes lo vieron levantar y derribar; parece ser que constaba de una planta centralizada inscrita en un rectángulo de perfil lobulado, en cuyo centro debería colocarse el sarcófago enmarcado por cuatro columnas a modo de baldaquino. En la parte superior se abriría una claraboya y sería decorado con mosaicos representando escenas de las novelas del escritor. La primera piedra del mausoleo se colocó alrededor de 1935, llegó a construirse el cuerpo principal y se decoraron dos nichos laterales, uno con escenas de Los cuatro jinetes del Apocalipsis y otro con el de los Argonautas. El sarcófago fue encargado a Mariano Benlliure Gil (1864-1947), amigo personal del escritor, que lo entregó en 1935 y que actualmente se conserva en el convento del Carmen, al igual que el féretro de madera de tamaño colosal que llevaba en la cubierta la inscripción Los muertos mandan, y el cual necesitó de cincuenta y dos equipos de veinte hombres para ser trasladado. El ataúd estaba decorado con motivos ornamentales en oro y relieves que representaban personajes de sus novelas, así como el escudo de Valencia y diversos motivos masónicos. ${ }^{26}$ Todo esto, como relataba Max Aub, quedó reducido a una sencilla tumba en el cementerio civil de la ciudad de Valencia, aunque muchas han sido las elucubraciones al respecto de la ubicación del cuerpo de Vicente Blasco Ibáñez a lo largo de los años; lo reseñable son las intenciones faraónicas de las autoridades del momento por levantar toda una escenografía en memoria del personaje

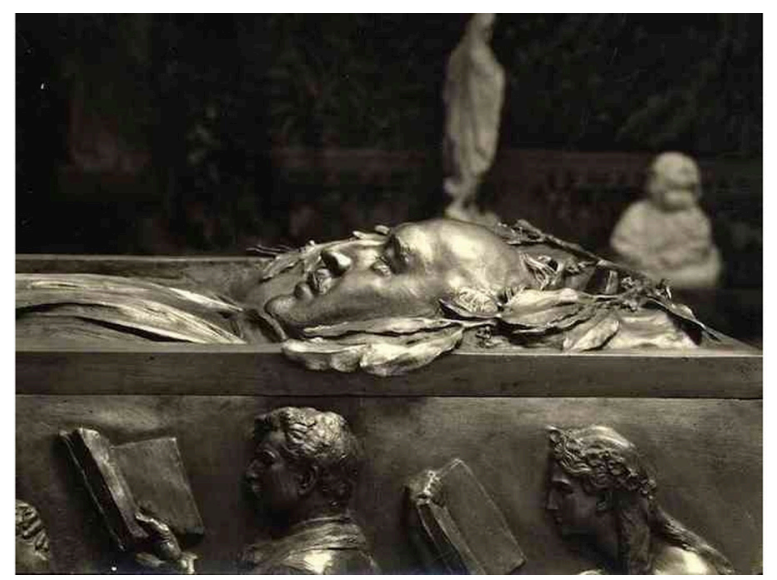

Fig. 5. Detalle del Sarcófago de Vicente Blasco Ibálñez, Mariano Benlliure, 1935, Fotografía Archivo Museo Benlliure, Crevillent, Valencia

26. MuÑoz Puelles: Informe, http://cort.as/-C7Wi (consultado el 04/3/2016), pp. 2-3; JAVIER VARELA: El último conquistador: Blasco Ibáñez (1867-1928), Tecnos, Madrid, pp. 940-943. Se podría señalar como influencia en la obra de Mariano Benlliure los trabajos realizados por Doménico Fancelli. El escultor trabajó mucho en España, fue y es reconocido por sus obras funerarias, como el sepulcro de los Reyes Católicos en la catedral de Granada. Se le considera uno de los introductores del gusto renacentista en España. Seguramente Mariano Benlliure conocería sus obras y sabría de su importancia. Esto junto con las influencias que recibiría de su larga estancia en Roma contribuirían a la elaboración del sarcófago de Vicente Blasco Ibáñez. 
público, y cómo finalmente por cuestiones políticas más que lógicas el cuerpo continúa en el lugar que seguramente el mismo difunto deseó.

El magno acontecimiento fue retratado desde la salida de Menton hasta la llegada al cementerio de Valencia por medio de un gran reportaje fotográfico. Las instantáneas nos permiten contemplar y recorrer el vía crucis que siguieron los restos de Blasco Ibáñez: las carrozas usadas en Francia para transportar el cuerpo, la llegada del ataúd al puerto de la ciudad, la arquitectura efímera construida para su recibimiento, el sepulcro obra de Mariano Benlliure, la multitud que lo acompañó en todo momento; cada paso fue escrupulosamente documentado por distintos artífices (figs. 6, 7 y 8).

En cuanto al escenario que se erigió en el puerto de Valencia para su recibimiento podemos señalar la influencia de las arquitecturas efímeras que se

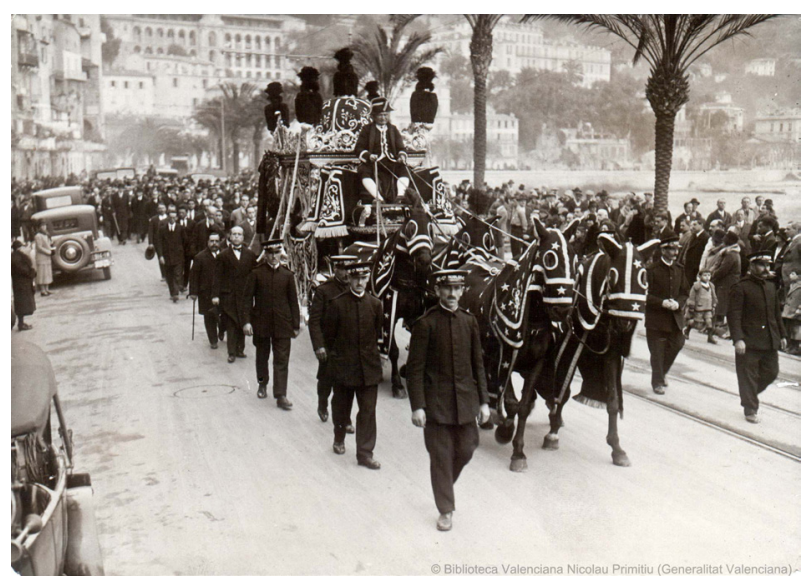

Fig. 6. Anónimo, Carrozas utilizadas para trasladar el cuerpo, 1928, Menton (Francia), Archivo Municipal de la Diputación de Valencia

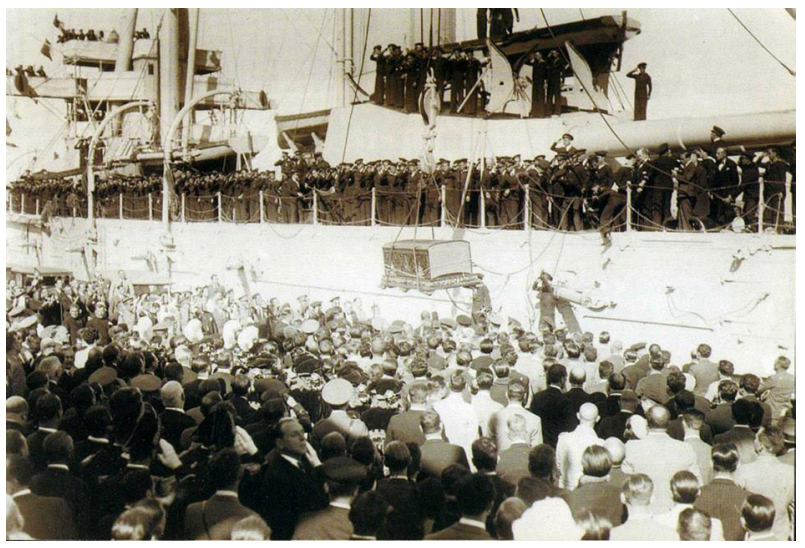

Fig. 7. Anónimo, Llegada de los restos del escritor a bordo del Jaume I a Valencia, 1933, Archivo Municipal de la Diputación de Valencia 


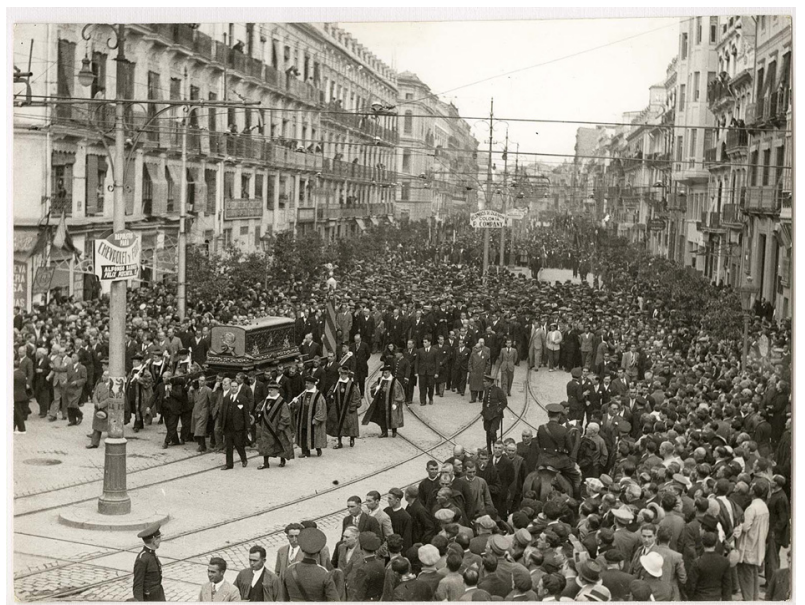

Fig. 8. Anónimo, Multitud acompañando el ataúd por las calles de Valencia, 1933, Archivo Municipal de la Diputación de Valencia

llevaron a cabo desde el Barroco en España (fig. 9). Como explica Pilar Pedraza: «todas las artes se ponían en juego para crear ámbitos y escenas artificiosas que sobrecogían el ánimo del espectador, deslumbrándole con un aparato y un fasto que le arrancaban temporalmente de la vida cotidiana». ${ }^{27}$ Tramoyas revestidas de tapices que contienen los pertinentes escudos y motivos vegetales; podemos suponer -a pesar de que la imagen sea en blanco y negro- que inundadas de color aprovechando la luz natural tan útil en este tipo de construcciones. El lugar estaría destinado a los altos mandatarios y personajes ilustres del ámbito público que aguardarían impacientes la llegada del pesado ataúd.

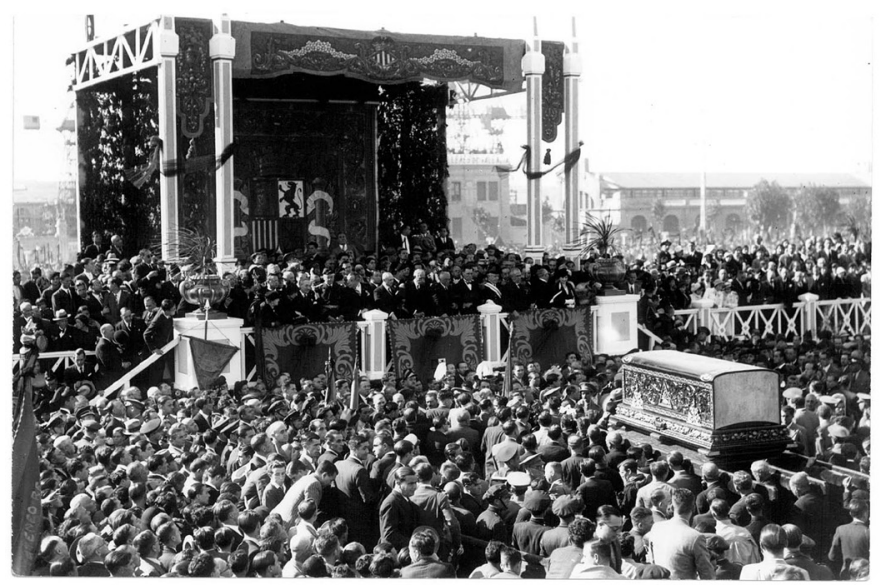

Fig. 9. Anónimo, Construcciones efímeras para recibir al escritor, 1933, Archivo de la Diputación de Valencia

27. Pilar Pedraza: Barroco efímero en Valencia, Ayuntamiento de Valencia, Valencia, 1981, p. 23. 
Recordamos que las honras fúnebres en honor a los grandes hombres surgieron y se desarrollaron en la Grecia clásica y la República romana, estableciendo referentes iconográficos posteriores. En España -como en la Roma imperial- estas ceremonias mantienen su función clásica: espectáculo de la representación del poder. Con el tiempo, la Monarquía y la Iglesia no serían las únicas beneficiarias de tales honores y de dichos espectáculos, eso sí, tal despliegue de medios siempre acaecía sobre figuras de orden público. Todo este artificio en torno al personaje de Blasco Ibáñez nos enseña el cuerpo representado, a modo de segundo сuеrpo, recogiendo la herencia medieval. Pues, los reportajes fotográficos en los que el profesional iba capturando todos las etapas del rito fúnebre no tienen como función el recordar el rostro del difunto, sino recordar el día de su muerte y su prez. Por supuesto, Vicente Blasco Ibáñez, además de ser beneficiario de todos los honores en su sepelio nacional tuvo también las consabidas fotografías post mortem.

Una vez recorrido en imágenes el periplo de los restos del escritor donde hemos apreciado la multitud de actos y símbolos ostentosos alrededor del personaje, volveremos al punto de partida, el cuerpo íntimo y real. Y hablamos en plural ya que hemos podido acceder a varias imágenes de diferentes fuentes: las propiamente denominadas retratos funerarios post mortem en las que se muestra el hombre solo en su lecho privado (figs. 10 y 11), y otras en el ataúd acompañado de familiares y autoridades del momento (fig. 12). Todas ellas, en el caso que nos ocupa, tendrían más una función pública que privada, pues nos referimos a un personaje ilustre y seguramente las fotografías estarían destinadas a medios impresos más que al mero recuerdo familiar, por lo tanto, nos enfrentamos nuevamente, como en los ejemplos franceses mencionados, a la cuestión de la memoria colectiva.

Es curioso cómo en la mayoría de los estudios, publicaciones o exposiciones que se han llevado a cabo sobre la figura del escritor resaltan los monumentos

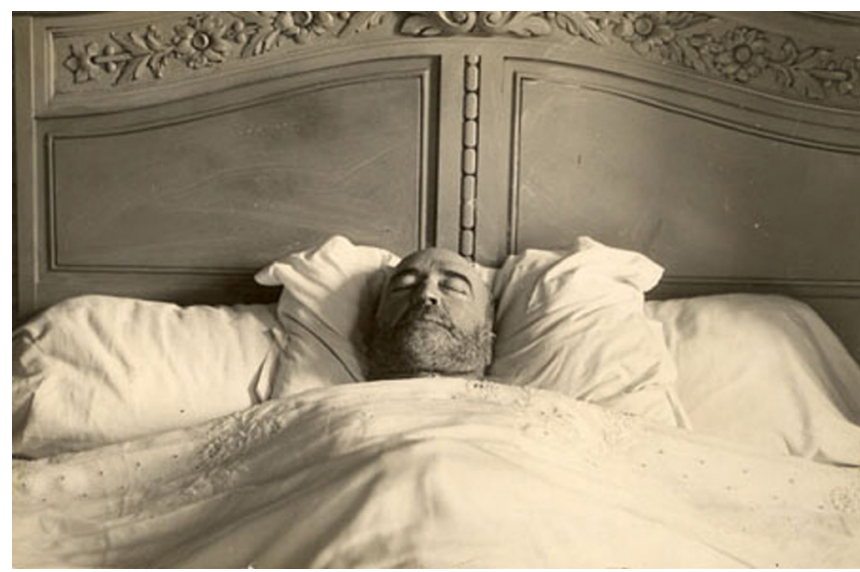

Fig. 10. Anónimo, Vicente Blasco Ibáñez en su lecho fúnebre, 1928, Archivo Gráfico de la Diputación de Valencia 


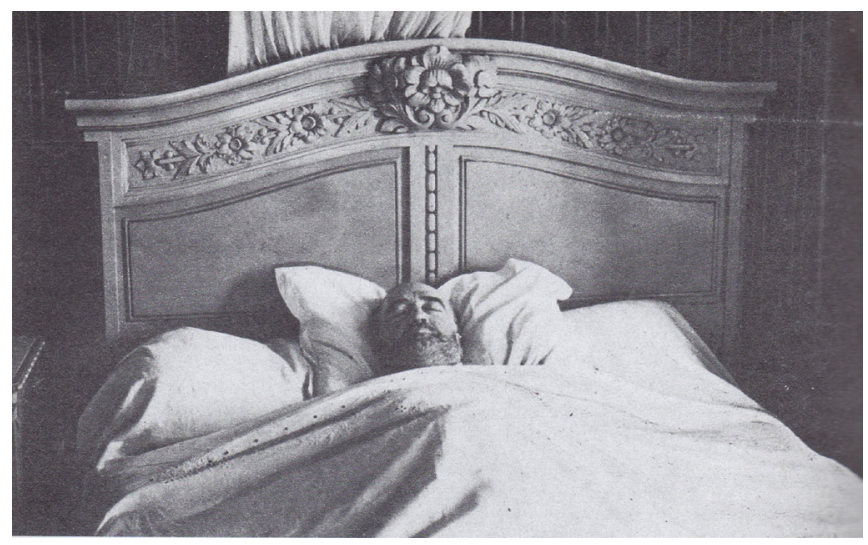

Fig. 11. Sin especificar, Vicente Blasco Ibáñez en su lecho fúnebre, 1928. Extraída: RocA, LEón: Blasco Ibáñez, Ajuntament de València, Valencia, 1997, p. 213

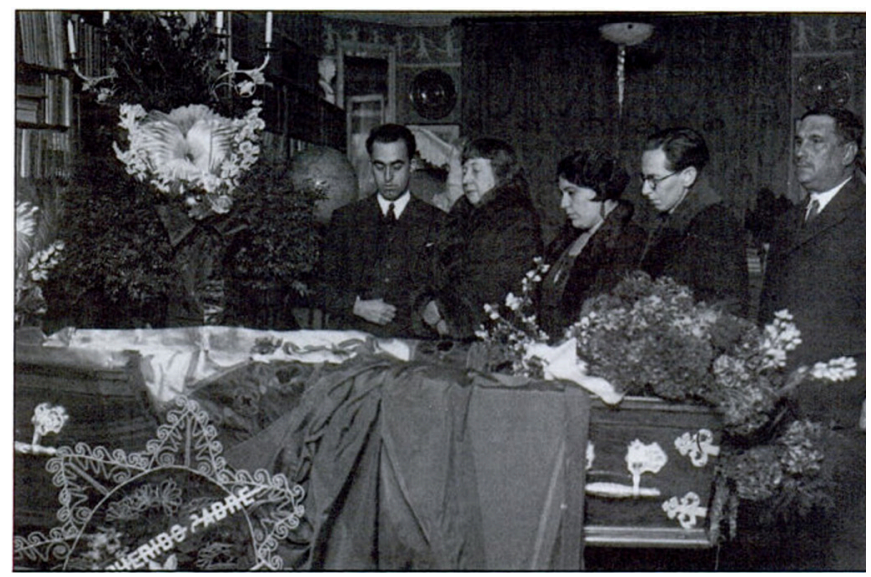

Fig. 12. Anónimo, Vicente Blasco Ibáñez y dolientes, 1928, Colección particular.

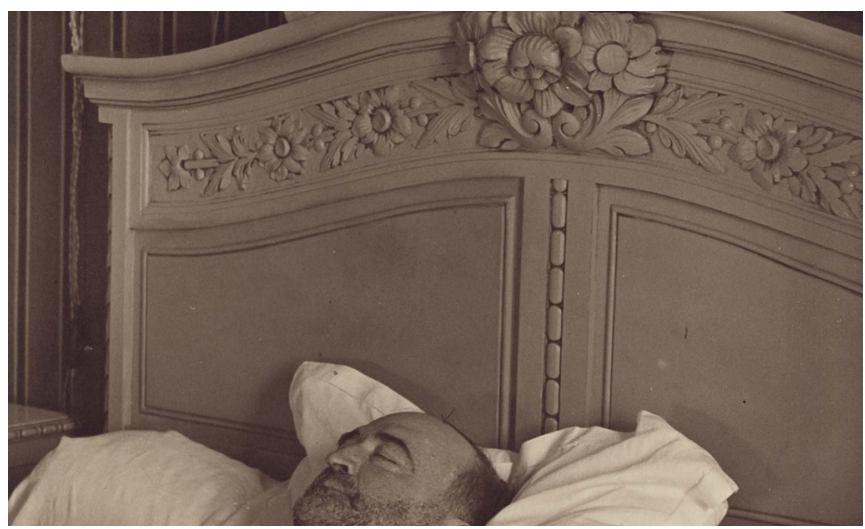

Fig. 13. Anónimo, Vicente Blasco Ibáñez en su lecho fúnebre, 1928, Archivo Gráfico de la Diputación de Valencia 
que se levantaron en su honor, quiénes los realizaron y los actos que le propiciaron. En cambio, no encontramos apenas información al respecto de las imágenes fotográficas del cadáver ${ }^{28} \mathrm{En}$ los dos archivos a los que hemos recurrido en busca de información sobre los fotógrafos -Archivo General de la Diputación de Valencia y la Casa-Museo de Vicente Blasco Ibáñez- han coincido en admitir que es complicado saber con seguridad quién realizó los diversos disparos, sin embargo, sí que nos han proporcionado algunos nombres, no sin alumbrar ciertas dudas. En el primer caso señalan como artífices, por los sellos del dorso de las imágenes, a G. Ruggieri en Menton y Lázaro en Valencia; en cambio la Casa-Museo nos habla de un enviado especial llamado Sr. Campúa, refiriéndose en concreto a las imágenes publicadas en el suplemento de Mundo Gráfico, remarcando que seguramente habrán otras imágenes tomadas por otros fotógrafos..$^{29} \mathrm{El}$ hecho evidencia sobre todo la diversidad de las imágenes que circulan del cadáver, pues en el caso del Archivo de la Diputación hemos podido acceder a las fotografías desde la web, sin embargo, la Casa-Museo no las posee digitalizadas, pero podemos aventurar que no se tratan de las mismas, pues ellos nos hablaban de una imagen en la que aparecía el cuerpo de Vicente Blasco Ibáñez junto al escultor Léopold Bernstamm y tomas del cuerpo de Vicente Blasco Ibáñez en prensa (fig. 14). ${ }^{30}$

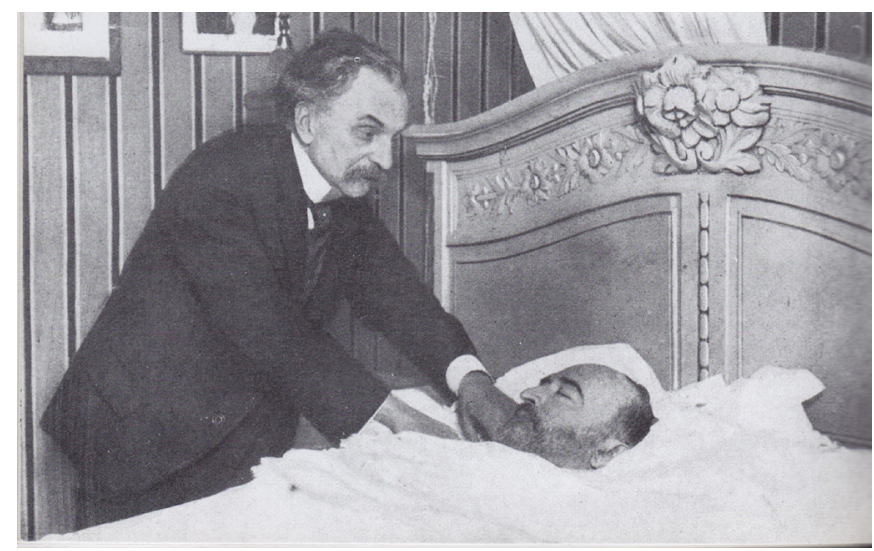

Fig. 14. Anónimo, Léopold Bernstamm sacando los moldes de Vicente Blasco Ibáñez, 1928.

Extraída: RocA, León: Blasco Ibáñez, Ajuntament de València, Valencia, 1997, p. 210

28. Si bien es cierto que se organizó una exposición en 2008 titulada El último viaje coincidiendo con el 75 aniversario de la llegada de los restos del escritor a Valencia, la muestra se centra en las imágenes del recibimiento, sin especificar nada sobre los retratos post mortem. FEDERICO Simón: «El último viaje de Vicente Blasco Ibáñez», El País, 12 de octubre de 2008; RiCARdo Rodríguez: «El último viaje de Blasco Ibáñez», en Levante, 12 de octubre de 2008.

29. Archivo General de la Diputación de Valencia (mail recibido el 21-X-2016); Villanueva, BelÉN. Casa-Museo Vicente Blasco Ibáñez (mail recibido 3/3/2017).

30. En la imagen citada se muestra el cuerpo sin vida del escritor al lado del escultor, el cual sostienen en sus manos el molde del rostro y las manos del muerto. Gracias a su existencia hemos descubierto que Vicente Blasco Ibáñez también tiene una máscara mortuoria -como nos relató vía mail Belén Villanueva, ésta además es propiedad del Ayuntamiento de Valencia- realizada por su amigo personal que también se ocupó de otras máscaras mortuorias como la de Fiódor Dostoyevski. 
Afortunadamente, pudimos acceder a la instantánea por medio de una fuente bibliográfica, y no solo eso, sino que también hallamos fotografías de los moldes del rostro y de las manos para la posterior factura de la máscara mortuoria (figs. 15 y 16).

Sin embargo, Javier Varela, en su minucioso estudio sobre la vida y la obra de Blasco Ibáñez, arroja algo de luz al asunto de las distintas tomas por los distintos artífices. Además de poner de relieve cómo una vez muerto el artista queda a merced de los últimos deseos de quienes le rodean y de cómo se puede manipular a través de la fotografía la realidad. Pues Varela afirma que Campúa, para el diario Mundo Gráfico, tomó una instantánea donde solamente se vis-
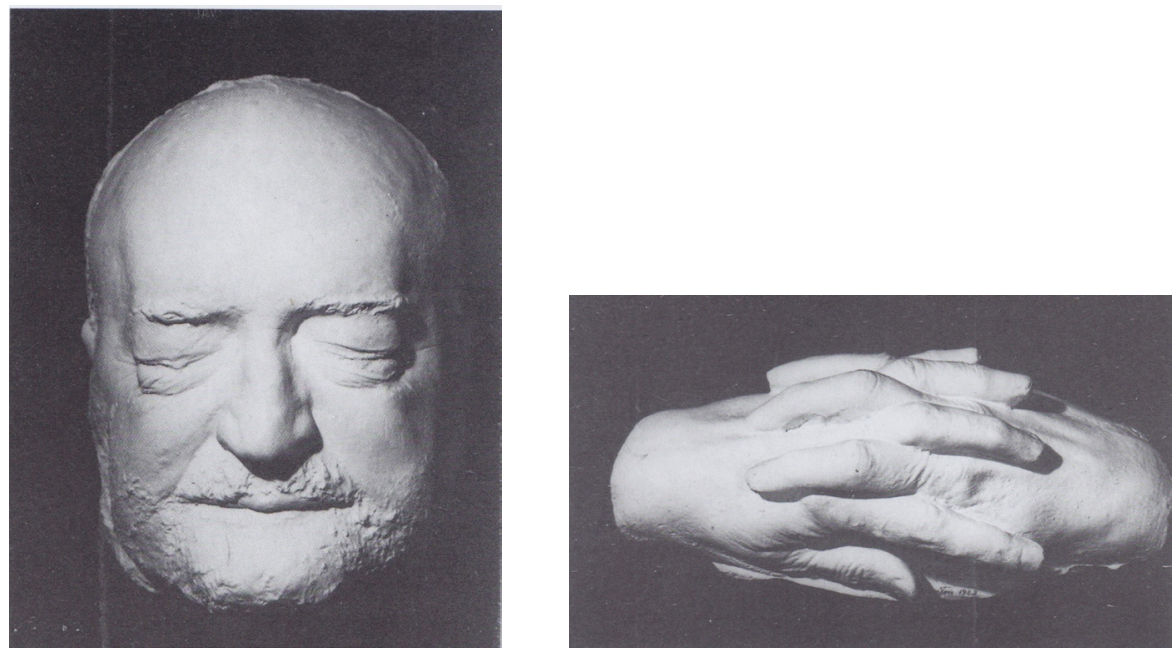

Fig. 15. Anónimo, moldes para máscara mortuoria, 1928. Extraída: RoCA, LEÓN: Blasco Ibáñez, Ajuntament de València, Valencia, 1997, p. 210

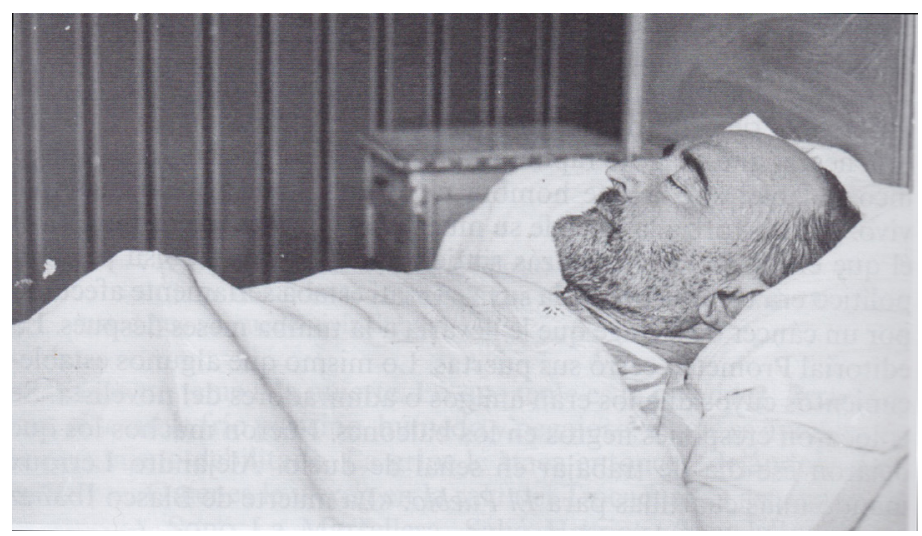

Fig. 16. Campúa, Vicente Blasco Ibáñez en su lecho de muerte, Mundo Gráfico, 1 de febrero de 1928. Extraída de: VARELA, El último conquistador., p. 928 
lumbra el rostro del fallecido de perfil libre de atributos, mientras C. Ruggieri para el diario Estampa adornó la mesita del fondo con elemento religiosos por iniciativa de su segunda mujer, concretamente con un Sagrado Corazón -símbolo que el escritor aborrecía-, lo que levantó las habladurías de los conservadores acerca de la conversión del artista en sus últimos momentos. ${ }^{31}$

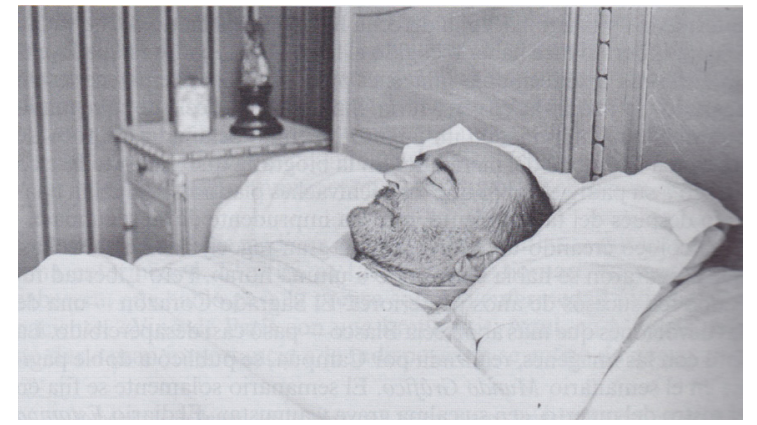

Fig. 17. C. Ruggieri, Vicente Blasco Ibáñez en su lecho de muerte, 1 de febrero de 1928, Extraída de: VARela, El último conquistador., p. 928

Finalmente, acudiendo a algunas de las fuentes impresas en la época, hallamos en la Biblioteca Nacional de España un ejemplar del Heraldo de Madrid que se ha convertido en una pieza clave de la investigación (fig. 18). En él, además de aparecer varias imágenes del cuerpo del escritor fallecido -distintas tomas del cadáver-, una firmada por el citado Ruggeri y otra proveniente del Petit Niçois, e incluir en la misma portada que se tratan de fotografías exclusivas para la publicación y enviadas por avión, incidiendo así en la supremacía con respecto a otras publicaciones, también detalla extensamente la muerte del artista y constata la tan ansiada buena muerte de los hombres ilustres. Recreándose en descripciones tales como:

Blasco Ibáñez parece dormir. Dentro de la caja mortuoria -de madera riquísima con fondo metálico- la cabeza reposa sobre una almohada blanca y el cuerpo está cubierto con un brocado blanco. Aquella cabeza: De una palidez de marfil viejo, la frente poderosa refleja la luz triste del día. Los ojos parecen entornados, con aquel gesto tan suyo [...] Sobre los labios apretados una mueca que tiene un dejo entre dolorosa y apacible, la línea ancha y parda del bigote sin recortar pone como un signo circunflejo sobre la apertura de los labios, de un rosa mortecino, amoratado. [...] Presidiendo la fúnebre estancia, una gran bandera de España despliega sus colores [...] Su hijo Mario pone junto a la bandera española uno de los retratos que adornaban la biblioteca. Es un retrato que lleva esta dedicatoria: A Blasco Ibáñez, simpático y afectuoso recuerdo de Emilio Zola. Octubre de $1902 .^{32}$

31. VArela: El último conquistador, 2015, p. 927.

32. Víctor Rico: «Ante el cadáver de Blasco Ibáñez», Heraldo de Madrid, 33.105, 30 de enero de 1928, p. 2. 


\section{HERALDO DE MADRID \\ LA DOLOROSA PERDIDA DE BLASCO IBÁÑEZ}

Los enviados especiales del HERALDO en

Menton relatan la muerte del grande hombre

(Cronicas de nuestros rodaclores Victor Rizo y Maluenda, y fotografias
exclusivas para ei HERALDO, transmitidias por avión)

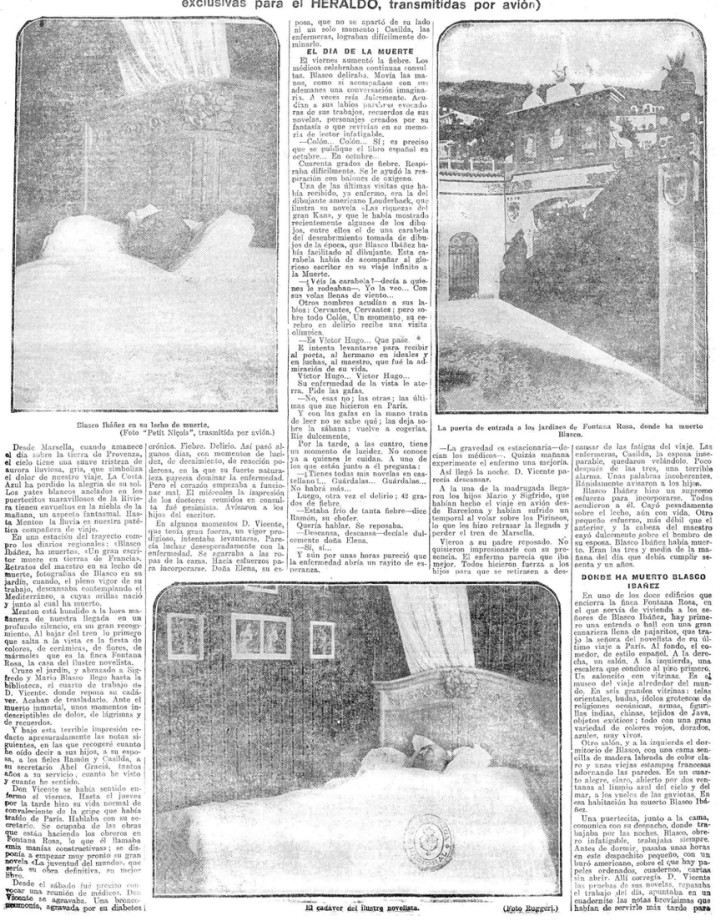

Fig. 18. Portada del Heraldo de Madrid, 1928, Biblioteca Nacional de España. Rico, Víctor. «Ante el cadáver de Blasco Ibáñez», en Heraldo de Madrid, n. ${ }^{\circ}$ 33.105, 30 de enero de 1928, p. 2

En resumen, hemos apreciado cómo se tomaron las instantáneas del cuerpo en soledad desde ángulos distintos, con toda probabilidad para ser usadas en diferentes medios, pues el objetivo de estas imágenes -incidimos- no es tanto el recordatorio de un ser querido como el registro de un hecho histórico. ${ }^{33} \mathrm{Sin}$ embargo, el encuadre, la disposición del cuerpo y la ausencia de elementos denotan un carácter marcadamente clásico confirmando lo que venimos viendo en las anteriores imágenes. Todos los retratos que hemos analizado tienen

33. Como formula Andrea Cuarteolo: «En el caso de los personajes públicos [...] era muy difícil que la fotografía post mortem fuera la única imagen que los retratara. Lo más frecuente era que contaran no con una sino con varias fotos tomadas en vida. En estos casos, además, la iniciativa del retrato raramente provenía de la familia. [...] Esta surgía, la mayoría de las veces, de los propios fotógrafos y hacia fines del siglo XIx fueron los mismos medios gráficos quienes comenzaron a encargarlas». ANDREA CUARTEOLO: La muerte ilustre, pp. 85-86. 
la particularidad de estar desprovistos de adornos, retratados los cuerpos de perfil, recostados en un cojín y enmarcados en blanco. El proceder de los fotógrafos es similar y pone en evidencia una idea: la muerte misma es la noticia, por lo tanto, no debe ser atenuada o disimulada, no es necesario ningún tipo de embellecimiento adicional más que el pertinente al tratamiento del cadáver, pues el fin de retrato mortuorio de un personaje público es el registro "pretendidamente objetivo de un hecho de actualidad para el consumo masivo». Pero la ausencia de decorado no implica ausencia de puesta en escena, ya que el intento de objetividad en el medio fotográfico -al igual que ocurre en la pintura o escultura- es una utopía. Toda fotografía contiene un punto de vista y una intención, como bien subraya John Berger:

El verdadero contenido de una fotografía es invisible, porque no se deriva de una relación con la forma, sino con el tiempo. [...] las fotografías testimonian una elección humana. [...] Los objetos registrados en cualquier fotografía (desde el más impactante al más común) transmiten aproximadamente el mismo peso, la misma convicción. Lo que varía es la intensidad con la que se nos hace conscientes de los polos de ausencia y presencia. Es entre esos dos polos donde la fotografía encuentra su significado (el uso más popular de la fotografía es como recuerdo de lo ausente). ${ }^{34}$

\section{EPÍlOGo}

Las nociones sobre la muerte atravesaron distintas acepciones durante el siglo xIx, dependiendo de las culturas que las desarrollaran como temas artísticos o traspasando las fronteras de los mismos. Un convulsivo siglo $\mathrm{xx}$, con sus cambios acelerados y sus grandes guerras, alargó la vida a unos al mismo tiempo que se la quitaba a otros; y, además, nos lo mostraba a todos. El arte empezó a poblarse de imágenes -documentales, artísticas, testimoniales- que nos enfrentaban a la muerte de desconocidos, alejándonos de la propia. Los medios enseñaban cuerpos esbeltos y cuerpos aniquilados, y aprendimos a convivir con ello.

El 30 de enero de 1928, la portada del Heraldo dedicaba a la despedida de Vicente Blasco Ibáñez un amplio reportaje. Los últimos momentos de una vida ocupaban la parte más destacada de un medio impreso y, además, no fue el único. No era la primera vez, ni será la última, en la que la prensa muestre al artista en sus últimos momentos, pero lo que resulta llamativo del hecho es el acercamiento con reminiscencias románticas al acontecimiento. Tanto las imágenes como el texto que las acompañan se encuentran revestidos de un fulgor de heroísmo: la lucha del gran hombre enfermo, un hombre con condición de artista, y su inevitable alcance. Por ende, intuimos que la intención

34. John Berger: La apariencia de las cosas, Gustavo Gili, Barcelona, 2014, p. 159. 
última de estas obras es aleccionar al espectador sobre cómo se debe morir, resaltando la idea de la dignidad de los personajes ilustres, incluso una vez muertos.

El tema de la naturaleza heroica del hombre asociado al principio humano de la trascendencia fue abordado por autores como Emerson, Nietzsche, Marx o Freud. Todos ellos recordaban -desde los inicios del pensamiento moderno- «que entre todas las cosas que conmueven a un ser humano, una de las más importantes es el terror a la muerte». ${ }^{35}$ La muerte como horror se impondrá conforme avancen los tiempos, pero quedará de forma latente restos de tiempos pasados. Al mismo tiempo que se rechazan los males que llevan a fenecer, el ser humano busca sus encantos. Quizá la fascinación por lo obsceno se base, como dijo Bataille, en que «con una venda sobre los ojos nos negamos a ver que sólo la muerte garantiza incesantemente una resurgencia sin la cual la vida declinaría». ${ }^{36}$

Podemos vislumbrar que las imágenes post mortem son arquetípicas, aplicables a todo un archivo generacional de retratos de difuntos, inspirados la mayoría de las ocasiones en composiciones escultóricas y pictóricas. A pesar de que podemos encontrar distintas tipologías, suelen ser composiciones desarrolladas en la historia del arte desde la época medieval, que encuentran en la fotografía una continuación lógica. De este modo, se consolidan estructuras escenográficas cultivadas durante el Renacimiento y el Barroco hasta recalar en las nuevas corrientes artísticas, que para ejercer todo su poder debían contener códigos fácilmente entendibles y arraigados en la tradición, creando finalmente unos modelos fotográficos que se perpetuarán a los largo del todo el siglo XIX y gran parte del Xx..$^{37}$

En definitiva, el destino de las imágenes de muerte atiende tanto a la necesidad política como al duelo masivo. Con el tiempo, su sino quedó ligado inevitablemente a los medios de comunicación. La frontera entre lo público y lo privado, que durante el siglo xix se había ido difuminando, queda ahora prácticamente desvanecida. Sumado a ello, la nostalgia ante la vida suscitada por dichas imágenes hace de estos temas de investigación campos en abierto, de los que queda mucho por estudiar. A menudo nos cuestionamos qué es la muerte mientras soportamos nuestras dolencias. Nuestra misión ahora es ahondar en las imágenes, sus engaños y realidades, para aportar luz a temas que han quedado prácticamente velados.

35. Estas ideas son recogidas por numerosos intelectuales dedicados a planos distintos del conocimiento. Entre otros encontramos: Ernest Becker: La negación de la muerte, Kairós, Barcelona, 2000, p. 41 o al antropólogo Louis-Vicent Thomas: Antropología de la muerte, Fondo de Cultura Económica, México, 1983.

36. George Bataille: El erotismo, Tusquets, Barcelona, 2013, p. 63.

37. Un amplio catálogo de imágenes post mortem en pintura podemos encontrarlo en el libro: MANUEL SÁnchez CAmargo: La muerte y la pintura española, Editorial Nacional, Madrid, 1954. 


\section{Bibliografía}

ArIÈs, PhILIPPE: El hombre ante la muerte, Taurus, Madrid, 1983.

- y Duby, George: Historia de la vida privada. La Revolución francesa y el asentamiento de la sociedad burguesa, Taurus, Madrid, 1991.

Aub, Max: La gallina ciega. Diario español, Alba, Barcelona, 1995.

Bataille, George: El erotismo, Tusquets, Barcelona, 2013

BAZIN, ANDRÉ: «Ontología de la imagen fotográfica», en ¿Qué es el cine?, Rialp, Madrid, 2000.

BeCKer, ERnest: La negación de la muerte, Kairós, Barcelona, 2000

Belting, Hans: Antropología de la imagen, Katz, Madrid, 2007.

Benjamin, WAlter: Sobre la fotografía, Pre-Textos, Valencia, 2013.

BenKard, ERnst: Rostros inmortales. Una colección de máscaras mortuorias, Sans Soleil, Barcelona, 2013

BERGER, John: La apariencia de las cosas, Gustavo Gili, Barcelona, 2014.

Bessy, Maurice: Mort où est ton visage?, Editions du Rocher, Mónaco, 1981.

Cruz, Virginia De La: El retrato y la muerte. La tradición de la fotografía post mortem en España, Temporae, Madrid, 2013.

CuARTeolo, Andrea: «La muerte ilustre. Fotografía mortuoria de personajes públicos en el Río de la Plata», en Imagen de la muerte, Universidad Nacional Mayor de San Marcos, Lima, 2007.

De La Torre Fazio, Julia: El retrato en miniatura español bajo los reinados de Felipe iI y Felipe III, Tesis doctoral, Universidad de Málaga, Málaga, 2009.

Debray, Regis: Vida y muerte de la imagen: Historia de la mirada en Occidente, Paidós, Barcelona, 1994.

Dubois, Philippe: El acto fotográfico. De la Representación a la Recepción, Paidós, Barcelona, 1986.

FReUnd, Gisèle: La fotografía como documento social, Gustavo Gili, Barcelona, 2011.

Héran Et Alt., Emmanuelle: La Dernier Portrait. Musée d'Orsay, 5 de mars-26 mai 2002.

Kantorowicz, Ernst H.: Los dos cuerpos del rey: un estudio de teología política medieval, Alianza Editorial, Madrid, 1985

LARA López, EMilio Luis: «La representación social de la muerte a través de la fotografía (Murcia y Jaén, 1870-1902): una historia de la imagen burguesa», en Revista de dialectología y tradiciones populares, 60, 2005.

López De Munain, Gorka: Una genealogía de la máscara mortuoria. Tiempo, imagen y presencia, Tesis doctoral, Universitat de Barcelona, Barcelona, 2017.

MíngueZ, Víctor: «Tumbas vacías y cadáveres pintados, el cuerpo muerto del rey en los jeroglíficos novohispanos, siglos XVII y XVIII», e-Spania, 17, 2014.

Muñoz Puelles, Vicente: Informe sobre los restos de Vicente Blasco Ibáñez, Consell Valencià de Cultura, 31 de marzo de 2005.

Pedraza, Pilar: Barroco efímero en Valencia, Ayuntamiento de Valencia, Valencia, 1981.

Rico, Víctor: «Ante el cadáver de Blasco Ibáñez», Heraldo de Madrid, 33.105, 30 de enero de 1928.

Rodríguez, Ricardo: «El último viaje de Blasco Ibáñez», Levante, 12 de octubre de 2008.

Ruby, Jay: Secure the Shadow. Death and Photography in America, Mit Press, Cambridge, 1995.

Sánchez Camargo, Manuel: La muerte y la pintura española, Editorial Nacional, Madrid, 1954.

Simón, Federico: «El último viaje de Vicente Blasco Ibáñez», El País, 12 de octubre de 2008

Thomas, Vicent: Antropología de la muerte, México, Fondo de Cultura Económica, 1983.

VAREla, JAVIER: El último conquistador: Blasco Ibáñez (1867-1928), Tecnos, Madrid, 2015.

VÁzQuez Casillas, José Fernando: «La fotografía como documento sociocultural a finales del siglo XIX: Nadar y el retrato post mortem», Revista de Dialectología y tradiciones populares, 2, vol. LXIX, 2014. 